\title{
Teaching Factory Learning Has Not Been Effective in Increasing the Entrepreneurial Spirit of Vocational High School Students
}

\author{
Agung Winarno'; Eting Kumala Sari² \\ Faculty of Economics, State University of Malang \\ E-mail: agung.winarno.fe@um.ac.id
}

\begin{abstract}
The purpose of this study is to determine the role of teaching factory implementation in Vocational High Schools in increasing the entrepreneurial spirit of students. This research used a descriptive qualitative research approach that is case studies; data collection is done by observation, documentation, and in-depth interviews. The results of the study showed that the implementation was carried out following industry standards, the evaluation was carried out during the process and performance of the final good/service. In general teaching, factoring can improve student skills in production, yet the development of entrepreneurial spirit relatively has not improved much. The main inhibiting factor of this learning is related to the lack of understanding of creating student entrepreneurial spirit but it is more focused on improving the student skill on production.
\end{abstract}

Keywords: teaching factory, entrepreneurial spirit, production skills

\section{INTRODUCTION}

Vocational education is one of the secondary education systems which prepares students especially can work better in one particular field of work (Bakar, 2018). One of the characteristics of vocational education is directed to prepare students for employment ("Authentic and self-directed learning in vocational education: Challenges to vocational educators - ScienceDirect," n.d.) and based on the needs of workforce. Vocational education has the aim of producing competent Vocational High School graduates who are ready to join the industrial world and have the ability to create their own jobs (Munastiwi, 2015).

Vocational (SMK) graduates who are expected to work directly or got employed in the workforce, yet in reality there are still many SMK graduates who find it difficult to get a job so they are unemployed. One of of the reasons is the teaching and learning in school has not integrated with the workforce itself yet. According to the Central Agency Statistics (BPS) in 2017, the unemployment rate for SMKs is the highest among other education levels, which is 11.41 percent. This number has increased from August 2016 by 11.11 percent.

Vocational education indeed prepares students to get involved in employment (Fuller, 2015), the current demand is that SMK graduates must not only be prepared as employees but must also be prepared to become entrepreneurs. Learning about entrepreneurial values is important considering the increasing number of SMK graduates from time to time. The benefits of learning entrepreneurship will not only make students get to know the ins and outs of the business world, sharpening talents, increasing self-confidence, increasing skills, stock of knowledge but also another 
important thing is how that someone knows how to make money, knows how to become a successful entrepreneur ("Students' reflections on the value of an entrepreneurship education - ScienceDirect, "nd). By getting introduction of entrepreneurship methods in the early age, at every level of the school, every graduate produced by all levels of education, even though the dropping out students has been prepared to be ready to become an entrepreneur (Saiman, 2015).

The characteristics of someone having an entrepreneurial spirit and attitude are full of confidence, optimistic, committed, disciplined, and responsible, full of energy, dexterous in acting and active, orientation to results and insight in the future, dare to be different, trustworthy and tough in acting, calculating or like challenges (Gedik, at.al, 2015). Entrepreneurial spirit is very appropriate to be instilled deeply and started early so that someone will learn more independently, think critically, creatively and innovatively and can see opportunities so those entrepreneurial potentials can arise in starting entrepreneurship.

In preparing competent graduates who are ready to work or set businesses, the government made a breakthrough by presenting a learning concept oriented to the Business World / Industrial World (DU / DI). This concept also bridges the gap between education in schools and the real industry (Chryssolouris, Mavrikios, Rentzos 2016). The concept which makes the school-life in vocational schools to get closer to the workforce is known as teaching factory (TEFA), the learning proclaimed by the government is teaching factory, which is a program designed for the development of production units namely the application of partner industry systems in existing production units (Damarjati, 2016). The teaching factory learning aims to foster the character and work ethic needed by DU / DI and to improve the quality of learning outcomes (Chryssolouris, Mavrikios, Rentzos 2016). Teaching factory integrates the learning process to produce goods and services that are worth selling. It can be interpreted that a teaching factory can be directed to instill an entrepreneurial spirit for students (DPSMK 2017). And this is important considering that entrepreneurship is one way to reduce the level of educated unemployment by creating graduates who have job maker capabilities (entrepreneurs), not job seekers (employees) (Dharmawati, 2016).

According to the Directorate of PSMK (2017) there are some basic values that must be developed to support the readiness of teaching factory implementation, namely: Sense of quality, which provides basic skills to students relating to quality objective standards; Sense of efficiency, equipping students with the ability to work efficiently; Sense of creativity and innovation, which teaches students to work creatively and innovatively. The teaching factory has a strategic value in increasing the competitiveness of graduates of vocational institutions such as vocational schools in the labor market because it has a mechanism that always follows the development of the industry very quickly (Mourtzis et al., 2018).

The teaching factory is a production / service-based learning concept that serves to bridge the gap between knowledge and skills acquired in 
schools and those in the industrial world. Based on the data and study exposure, this study seeks to determine the role of teaching factory implementation in increasing the entrepreneurial spirit of vocational students in Malang.

\section{METHOD}

The approach used in this research is a descriptive qualitative that is case study. The key informants consisted of five students who had conducted a teaching factory majoring in fashion and catering, two teachers, Vice Principal of Curriculum, and the Chair of the Expertise Program. The location of this research was State Vocational School in Malang which has implemented TEFA learning. The data collection was done by non-participant observation, in-depth interviews, and documentation. The credibility test was done by extending the observation, increasing perseverance, and triangulation of sources as well as technical triangulation. Analysis of research data was done through the process of data reduction, data presentation, then drawing the conclusion.

\section{RESULT \& DISCUSSION}

The implementation of the teaching factory (TEFA) in SMK is a form of one of the efforts of the Directorate of PSMK to strengthen cooperation between SMKs and industry (Rentzos et al., 2014). From the interview results, it is known that the time of implementing work or teaching factory practices uses a block system/block schedule so that it is different from other classes. Existing facilities and infrastructure are quite complete following industry standards and can do the work of teaching factory products even though some machines are broken and the number is less than total number of the students. Student activities at the teaching factory follow the SOP, so the products produced are industry standard. In the culinary department, students are involved starting from planning the menu to be served, to the evaluation process. Whereas in the fashion department, student activities only produce (assembling) orders from industry according to industry SOPs, finishing (checking) products, and packing.

Evaluations conducted at the teaching factory are evaluated at the time of the production of goods/services and product evaluations to find out the weaknesses and strengths of teaching factory by students, then made improvements after an evaluation. From the interviews in the implementation of the teaching factory, the supporting factors are teachers who are competent in their fields, school systems, and supported management, supported school environment, adequate facilities and infrastructure as well as industry standards of good cooperative relations with DU / DI, also support from trustees student. While the inhibiting factors are related to the initial funding for the procurement of teaching factory, skills and students' work ethics, arranging learning schedules, as well as the sustainability of teaching factory programs (continuity) also difficulties in finding partners from DUDI that are following the characteristics the schools want. 
Based on the deepening related to the students' interest in entrepreneurship after participating in the teaching factory program, data was obtained that during learning they were able to improve their skills in making products and services also increased self-confidence in producing (goods/services). The other finding is students who have prior business are eager to improve his business after graduating later. The role of teaching factory in growing and enhancing students' entrepreneurial spirit is considered less effective for students who have no prior business experience, and are different from students who have experience opening similar businesses with TEFA locations.

Based on research findings, Teaching factory is a form of learning that involves students actively and directly involved in actual work practices (Chryssolouris et al., 2016; Rentzos et al., 2014), by being directly involved thus the process of increasing student competency will be achieved and measured, students are also involved in the process from planning to the implementation of production and real service performance, according to (Rentzos, et al, 2014) will provide a lot of meaningful experience. This learning model also provides active learning (Chryssolouris et al., 2016) and helps students can construct their knowledge well (Rentzos et al., 2015), this is equivalent to constructivist learning (Rahman and Scaife, 2012) thus mutual cooperation profitability between schools and the business world becomes strategic in developing graduate competencies (İşgören et al., 2009).

The implementation of teaching factory block system is also one of the solutions to overcome the limitations of several production equipment or machines in schools that are on average less balanced with total number of the students ("The effect of block scheduling high school mathematics courses on student achievement and teachers' use of time: implications for educational productivity - ScienceDirect, "nd), the block model can be a solution to improve student performance. This is following the condition of facilities in the form of tools or machines whose numbers are not yet proportional to the total number of students. The implementation of teaching factory in Vocational Schools in addition to its main activity is production (producing goods/services), students are also involved in other activities during learning start from planning, preparing, producing, checking, packing and evaluating. Since the role of students in the context of production acts as an implementer and assessor (QC/quality control) (Directorate of PSMK, 2017). Thus, the goods/services produced are following industry standards, given the demands to produce according to the SOP of the business world. In general, TEFA implementation has met the requirements as set by the Directorate of PSMK (2017) which requires the involvement of three industry disciplines for students, namely (1) discipline of producing goods/services on time according to the time promised or targeted, (2) quality discipline/quality, about producing goods/services of the promised quality, precision and on time, and (3) disciplined procedures, about following the mandatory procedures (SOP). 
The results also showed that the average implementation in the field, TEFA learning was still found several inhibiting factors of the competency achievement effectiveness that is still limited business world that meets the requirements and willing become the school partner as a place of student learning. There are not many businesses that consciously commit to participate in developing students with integrated programs; even there are schools that in achieving this competency by producing in schools through their own laboratories. The scheduling problem also becomes an obstacle between the time programmed by the school and the available time in the business world version ("Influence of learning in resource-constrained project scheduling - ScienceDirect," n.d.)

The findings showed that the entrepreneurial spirit of students still has not reached much development. This was indeed realized by the parties considering that this learning is more focused on how students have experience of producing in the real world of business. This also causes that this learning has not been able to reach the aspects related to the formation of student entrepreneurial spirit, whereas when viewed from the additional purpose of this program is how to prepare graduates to become entrepreneurs, this finding is different from Fuller's idea, (2015) that one of the attitudes need to be formed through the vocational learning process is the formation of an entrepreneurial spirit, through strengthening competencies that are not only hard-skills, but also cognitive skills and attitudes (soft-skills) such as being disciplined, able to communicate and cooperate in teams, able to deal with customers, face risk which is a way for character building as an entrepreneur ("Disentangling competences: Interrelationships on creativity, innovation and entrepreneurship ScienceDirect," nd). The results showed that students' entrepreneurial interest after attending the teaching factory program increased only for students who had done business practices previously, this is because students had also been able to make products based on industry standards and cooperate directly with the industry and deal directly with customers and also supported by the subject of entrepreneurship (Barba-Sánchez and Atienza-Sahuquillo, 2018). According to the research findings, it is also known that the role of teaching factory has not been able to foster and enhance student entrepreneurial spirit, if it is associated with Winarno's (2015) findings that indirect entrepreneurial spirit will automatically increase along with increasing students' skills and experience in producing goods/services, growing the entrepreneurial spirit needs to be specifically designed with a particular learning model (Winarno, 2009), however the TEFA learning model is an alternative in growing interest in entrepreneurship, considering that in this learning process students directly or indirectly have introduced them how to management real business as well as help them in understanding to analyze strategies for entrepreneurship from the industry (Ismail et al., 2015). 


\section{CONCLUSION}

The teaching factory implementation in SMKs was generally done with good planning, and in practice, the process used a block system. During the process, students were taught to produce goods/services based on standards set by the industrial world. TEFA learning is effective in increasing the ability of students to produce and service consumers, but it is not effective to improve the spirit of entrepreneurship. This learning model is very useful for students who already have a business previously because work experience in the industry has been able to increase self-confidence, motivation for entrepreneurship and more understanding in business management. The main obstacle to TEFA learning lies in the difficulty of selecting an appropriate business world and the commitment of the business community in developing the entrepreneurial spirit of students. The advice given is the need to build a joint commitment between DUDI and Vocational School both in arranging schedules, curriculum and especially concerning the formation of students' entrepreneurial spirit.

\section{REFERENCES}

Authentic and self-directed learning in vocational education: Challenges to vocational educators - ScienceDirect [WWW Document], n.d. URL https://www.sciencedirect.com/science/article/pii/S0742051X10001 99X (accessed 11.8.19).

Badan Pusat Statistik., 2017. Tingkat Pengangguran Terbuka (TPT) sebesar 5,50 persen (online), (https://www.bps.go.id/pressrelease/2017/11/06/1377/ agustus2017--tingkat-pengangguran-terbuka--tpt--sebesar-5-50-persen.html), diakses 6 Oktober 2018.

Bakar, R., 2018. The influence of professional teachers on Padang vocational school students' achievement. Kasetsart Journal of Social Sciences 39, 67-72. https://doi.org/10.1016/j.kjss.2017.12.017

Barba-Sánchez, V., Atienza-Sahuquillo, C., 2018. Entrepreneurial intention among engineering students: The role of entrepreneurship education. European Research on Management and Business Economics 24, 53-61. https://doi.org/10.1016/j.iedeen.2017.04.001

Chryssolouris, G., Mavrikios, D., Rentzos, L., 2016. The Teaching Factory: A Manufacturing Education Paradigm. Procedia CIRP 57, 44-48. https://doi.org/10.1016/j.procir.2016.11.009

Dharmawati, M., 2016. Kewirausahaan. Jakarta: Rajawali.

Direktorat PSMK., 2017. Tata Kelola Pelaksanaan Teaching Factory. Jakarta: Direktorat Jendral Pendidikan Dasar dan Menengah Kementerian Pendidikan dan Kebudayaan Republik Indonesia.

Disentangling competences: Interrelationships on creativity, innovation and entrepreneurship - ScienceDirect [WWW Document], n.d. URL https://www.sciencedirect.com/science/article/abs/pii/S1871187114 000789 (accessed 11.8.19). 
Fuller, A., 2015. Vocational Education. International Encyclopedia of the Social \& Behavioral Sciences (Second Edition), 232-238. Dari https://www.sciencedirect.com/science/article/pii/B9780080970868 920919

Gedik, S., Miman, M., Kesici, S, M. 2015. Characteristics and Attitudes of Entrepreneurs Towards Entrepreneurship. Procedia - Social and Behavioral Sciences, 195, 1087-1096. Dari https://www.sciencedirect.com/science/article/pii/S1877042815036 320

Influence of learning in resource-constrained project scheduling ScienceDirect [WWW Document], n.d. URL https://www.sciencedirect.com/science/article/abs/pii/S0360835215 002661 (accessed 11.8.19).

İşgören, N.Ç., Çınar, A., Tektaş, N., Oral, B., Büyükpehlivan, G., Ulusman, L., Öznaz, D., Polat, Z., Uzmanoğlu, S., 2009. The importance of cooperation between vocational schools and industry. Procedia - Social and Behavioral Sciences 1, 1313-1317. https://doi.org/10.1016/j.sbspro.2009.01.232

Ismail, V.Y., Zain, E., Zulihar, 2015. The Portrait of Entrepreneurial Competence on Student Entrepreneurs. Procedia - Social and Behavioral Sciences 169, 178-188. https://doi.org/10.1016/j.sbspro.2015.01.300

Mourtzis, D., Vlachou, E., Dimitrakopoulos, G., Zogopoulos, V., 2018. CyberPhysical Systems and Education 4.0 -The Teaching Factory 4.0 Concept. Procedia Manufacturing 23, 129-134. https://doi.org/10.1016/j.promfg.2018.04.005

Munastiwi, E., 2015. The Management Model of Vocational Education Quality Assurance Using 'Holistic Skills Education (Holsked).' Procedia - Social and Behavioral Sciences, The 4th World Congress on Technical Vocational Education and Training (4thWoCTVET), 5-6 December 2014, Universiti Tun Hussein Onn Malaysia, MALAYSIA 204, 218-230. https://doi.org/10.1016/j.sbspro.2015.08.144

Rahman, F.A., Scaife, J., 2012. Sustaining Constructive Learning Environment: The Role of Multi-sources Regulation. Procedia - Social and Behavioral Sciences 35, 180-186. https://doi.org/10.1016/j.sbspro.2012.02.077

Rentzos, L., Doukas, M., Mavrikios, D., Mourtzis, D., Chryssolouris, G., 2014. Integrating Manufacturing Education with Industrial Practice Using Teaching Factory Paradigm: A Construction Equipment Application. Procedia CIRP 17, 189-194. https://doi.org/10.1016/j.procir.2014.01.126

Rentzos, L., Mavrikios, D., Chryssolouris, G., 2015. A Two-way Knowledge Interaction in Manufacturing Education: The Teaching Factory. Procedia CIRP 32, 31-35. https://doi.org/10.1016/j.procir.2015.02.082

Saiman, L., 2015. Kewirausahaan: Teori, Praktik dan Kasus-Kasus (Edisi 2). Jakarta: Salemba Empat.

Students' reflections on the value of an entrepreneurship education ScienceDirect [WWW Document], n.d. URL 
https://www.sciencedirect.com/science/article/abs/pii/S1472811714 000469 (accessed 11.8.19).

Sudiyanto., Sampurno. Y. G., \& Siswanto., 2013. Teaching Factory di SMK St. Mikael Surakarta. Jurnal Taman Vokasi 1(1). Dari http://jurnal.ustjogja.ac.id/index.php/tamanvokasi/article/view/134 The effect of block scheduling high school mathematics courses on student achievement and teachers' use of time: implications for educational productivity - ScienceDirect [WWW Document], n.d. URL https://www.sciencedirect.com/science/article/abs/pii/S0272775701 000450 (accessed 11.8.19).

Winarno, A. 2009. Internalisasi Nilai-nilai Kewirausahaan:Pendekatan Fenomenologi pada SMK Negeri 3 Malang, Disertasi, tidak diterbitkan, Malang, Program Pascasarjana, Universitas Negeri Malang Winarno, A. 2015. Pendidikan Kewirausahaan SMK dengan K-13: Perspektif Guru dan Sekolah. Prosiding: Seminar Nasional Ekonomi Manajemen Dan Akuntansi (SNEMA). Fakultas Ekonomi Universitas Negeri Padang. http://fe.unp.ac.id/sites/default/files/unggahan/13.\%20Agung\%20Wi narno\%20(hal\%20237-243) 0.pdf 